\section{From conflict to cooperation: Bertrand Russell, Norman Thomas, and the cold war}

\begin{abstract}
A significant number of historians have in recent years become participants in a bitter and protracted debate about the origins, nature, and impact of American involvement in the Cold War. This controversy has centered on an argument about the extent of American responsibility for the Cold War with a number of brilliant revisionist historians insisting that the traditional interpretation by both liberals and conservatives has relied too heavily on the official United States version that the genesis of all evil in the postwar era was the expansionist world-Communist movement directed by the Soviet Union. ${ }^{1}$ If recent books and journal articles are any indication, it appears that the battle over the methodology and basic premises of the revisionist critics and their traditionalist counterparts has provided sufficient fuel for a continuation of the debate for some time to come. ${ }^{2}$ It is not the intention of this study to provide additional ammunition for the participants in this continuing controversy.

Regardless of where the personal preferences of individ-

${ }^{1}$ See, for example, the following excellent historiographic discussions of this issue which appear in the Newsletter of the American Society for Historians of Foreign Relations: Norman Graebner, "The State of Diplomatic History", 4 (March 1973), 3-11; Arthur P. Whitaker, "Aren't We A1l Revisionists?", 4 (June 1973), 2-10; Thomas J. Noer, "The Changing Concept of Containment", 5 (Sept. 1974), 4-13.

${ }^{2}$ See Robert James Maddox, The New Left and the Origins of the Cold War (Princeton: Princeton University Press, 1973) for a characterization and critical discussion of the major revisionists; see also Geoffrey S. Smith, "Harry, We Hardly Knew You: Revisionism, Politics and Diplomacy, 1945-1954", American Political Science Review, 70 (June 1976), 560-82.
\end{abstract}

ual historians lie vis-à-vis the highly polarized historiography of the Cold War period, most would agree that the American response to the Cold War, and particularly the passion for security reflected in its overreaction to the dangers of internal Communist subversion, left a residue of bitterness and divisiveness that lingers to this day. One only has to examine Allen Weinstein's continuing attempts to sort out the truth from the emotion and partisanship surrounding the Hiss and Rosenberg cases to realize the validity of this point. ${ }^{3}$ Whispers about the dangers of internal subversion still lurk in (and occasionally emerge from) the shadows of the fantasy world of the radical right and, more significantly, in the ambiguous reminiscences of respected conseratives and liberals. Many, to put it bluntly, have never come to satisfactory terms with this issue.

One of the best examples of the conflict generated by the American reaction to the internal security question appeared in the correspondence of Norman Thomas, the American Socialist leader, with Bertrand Russell in the late 1950s and early 1960s. The dispute broke into the open when Thomas published "Norman Thomas Writes: An Open Letter to Bertrand Russell" in the 7 January 1957 issue of The New Leader, the official journal of the American Socialist party. ${ }^{4}$ In it, Thomas sharply criticized Russell for his highly negative depiction of civil liberties in the United States during the Cold War years presented in his "Foreword to the English Edition" of Corliss Lamont's book, Freedom Is As Freedom Does, and reprinted in the second American printing of that book. ${ }^{5}$

After briefly acknowledging his great debt to Russell for his "... straight thinking and cogent writing on philosophy and social problems of enormous significance to mankind", Thomas leaped to the attack ("Open Letter", p. 15). The essence of his critique was that Russe11's introduction was an exaggeration which both demoralized Americans and made British understanding of America more difficult. Thomas expressed surprise that a person concerned with mathematical accuracy and logic could have accepted without more inquiry al1 of Lamont's statements about both the McCarthyites, whom Thomas insisted had grown steadily weaker, and against persons whose reputations had not been soiled by

\footnotetext{
${ }^{3}$ A1len Weinstein, "On the Search for Smoking Guns: The Hiss and Rosenberg Files", The New Republic, 175 (14 Feb. 1976), 16-21.

${ }^{4}$ The New Leader, 40 (7 Jan. 1957), 15-16.

${ }^{5}$ Corliss Lamont, Freedom Is As Freedom Does (London: Calder, 1956), pp. ix-xii; (New York: Horizon, 1956 [2nd printing]), pp. ix-xii.
} 
... the application of a double standard: extraordinary leniency in judging Communist crimes and great severity in denouncing, somewhat uncritically, every American abridgement of liberty in our exaggerated concern for security.

Thomas then proceeded to list examples of Corliss Lamont's soft attitude towards Communism as proof that the latter applied a double standard in his political judgments. He noted that Lamont had in the 'thirties defended the Moscow purge trials and remained silent when Communists attacked John Dewey as a Fascist for declaring that the trials of Trotsky and others were rigged. Thomas did admit that Lamont had some years later become "mildly critical" of Soviet Communism, but that he had belittled the number of prisoners in Russian labor camps. He concluded his cataloguing of Lamont's sins by posing a question for Russell:

Suppose Mr. Lamont had been an American concerned, with some reason, for the state of American civil liberties, who, back in the Thirties, had made the same kind of defense of Hitler's regime which he offered of the Stalinist terror. Would you uncritically have written an introduction to his book without independent examination into its allegations?

Although he obviously disliked Lamont intensely Thomas left no doubt that his critique was motivated primarily by his hatred of Communism and his fear that Russell had unwittingly lent his good name to the dissemination of views that were sympathetic to it. ${ }^{6}$

Even worse than his support of Lamont's view, Thomas argued, was Russell's tendency to "... go rather beyond it in statements which his book does not properly support". Particularly objectionable to Thomas was Russell's charge that anybody who supported equal rights for Blacks or was sympathetic to the U.N. would be terrorized by the F.B.I. and encouraged to denounce their friends. This, Thomas thought, was so exaggerated "... as to approach falsehood".

Thomas admitted that there had been terrible miscarriages of justice against individual liberties in the Smith Act prosecutions (which, he reminded Russe11, the Communists had hailed earlier when Trotskyites and pro-Nazis were being charged), as well as in loyalty and security proceedings and in activities where the F.B.I. was involved. Nevertheless, he insisted that it was untrue that the F.B.I. interferred

${ }^{6}$ Thomas had been the prime mover in getting Communists expelled from the National Board of Directors of the American Civil Liberties Union, a move which Mr. Lamont had adamantly opposed. with citizens supporting racial equality and the U.N. He noted that economic coercion and social pressure were far less common than Russell had implied and that when they did occur they were generally the work of unofficial vigilante groups rather than the F.B.I. Thomas closed his discussion of Russell's exaggerations by dismissing as farfetched his comparison of the hysteria in American society with that found in France in 1793.

Thomas concluded his letter by emphasizing that he had not been a passive bystander where civil liberties were concerned.

I am deeply anti-Communist--as, I think, are you--but that has not prevented me from fighting our Smith Act and spending time and money in defense of certain of its Communist victims. I do not boast when I say that I have better earned my right to correct the record than you to advance your sweeping charges.

Bertrand Russell's response to Thomas was not long in coming. In a long letter which was published in the 18 February 1957 issue of The New Leader, Russell defended the assertions he had made in his introduction to Lamont's book. ${ }^{8}$ Russell opened by expressing regret that Thomas had thought it necessary to publish his open letter because: "You and I are on the same side in most matters, and I have every wish to avoid magnifying our differences".

Russe11 then discussed his own attitude toward Communism, emphasizing that he was as much opposed to Soviet totalitaria nism as Thomas was and perhaps more so because he had objected more strongly than the American to the "pale imitation" of Russian techniques in the United States. He emphasized that it was important to understand that evils could not be overcome by "blind hatred" because it would "... only lead us to become like them". To Russe11, the important thing was to get beyond the hatred and develop an understanding of the reasons why Communists and Nazis resorted to torture and terrorism, if such actions were to be prevented in the future.

Russell thus implied that Thomas, because of his hatred of the evils of Communism, failed to see the parallel be-

7"Open Letter", p. 16; Thomas' work on behalf of Alexander Trachtenberg and other former leaders of the Communist party of the United States who had run afoul of the Smith Act stands as proof of his sincerity on this point.

"Bertrand Russell Replies to Norman Thomas: The State of U.S. Civil Liberties", The New Leader, 40 (18 Feb. 1957), $16-18$. 
tween the guilt shared by fellow-travellers who refuse to admit Communist crimes and the guilt of anti-Communists who "... share the guilt of admittedly lesser crimes committed by the police and the law courts in the United States". Russell believed that Thomas' failure to sse that the two kinds of behaviour were related indicated that he lacked the proper perspective to arrive at understanding.

Somewhat ironically, Russell then accused Thomas of the same thing which the latter had accused him: ignorance of the actual state of civil liberties in the United States. Insisting that he did "... not think that ignorance in the face of available evidence is a valid excuse for those who make public pronouncements", Russe11 urged Thomas to do some reading before he made more public comments and proceeded to provide him with an annotated list of suggestions. He began by urging Thomas to read Max Lowenthal's critical book, The Federal Bureau of Investigation. Russell used it to support his charge that the F.B.I. had grown increasingly powerful since World War I; and in that time, it had operated "... with a disregard for law, truth and common humanity". Anticipating Thomas' rebuttal, he asserted that:

You will doubtless say that things have grown better since the fall of McCarthy, just as Communists say that things have grown better since the death of Stalin; but I am afraid the improvement is as temporary in the one case as in the other.

Here again, Russell continued to insist on his parallel interpretation, adhering to a rather fixed conception of the state of both Russian and American societies.

Turning to Thomas' criticism that he had written an introduction to a work by a notorious fellow-traveller, Russe11 noted that he had stated, with Lamont's approval, that he felt Russian restrictions on liberty were worse than those in the United States. Russe11 then explained that his real reason for writing the introduction was that: "I was led to do so by the extreme paucity of strong protests by non-Communists against American malpractices". Asserting that he had been roundly condemned by both Russians and Americans recently, Russell said: "Whoever pursues even-handed justice must expect to incur the hostility of both sides". Russell lacked no confidence about his abilities as an arbiter of international morality. Continuing, Russel1 asserted that a lot of American hostility towards him was caused by his stand on the Rosenberg and Sobel spy cases. He charged that the principals in those cases "... were condemned on evidence which no un- biased person could think conclusive". As evidence for his stance, he cited Malcolm Sharp's book, Was Justice Done?, and emphasized that the author was not a Communist or a fellow-traveller. On a related point, Russell found proof that an atmosphere of hysteria existed in America because "... if a man is accused of the sort of crime that Communists are expected to commit, anybody who thinks that he did not commit it is supposed to be a Communist".

Regarding Thomas' related criticism that he had listed violations of civil liberties which Lamont's book did not properly support, Russell repeated his charge that the championship of Black rights was regarded as evidence of Communism in the South and by the heads of some government security agencies. He cited Cedric Belfrage's volume, The Frightened Giant, as proof of this point. Admitting that he had "... perhaps said more than Lamont about the way in which a general state of terror has been produced", Russel1 cited as proof the letter of an American professor which had been published in the 18 July 1954 issue of the London observer. In it, that professor had related how he had lost his job, home, library, and chances for another job because he had defended a non-Communist friend with leftish political ideas. Russe11 insisted that Thomas lacked "... the vaguest idea of the general state of fear which exists in American universities among young professors and instructors and among intelligent students".

Russe11 concluded his letter by noting that: "In every violent conflict, party spirit produces a tendency to excuse or cover up the crimes committed by one's own side". Citing the Russian suppression of the Hungarians as a terrible atrocity, Russell reminded Thomas that it did not justify the conviction of Americans when inadequate evidence was presented against them. Consequently, he urged Thomas to "... study the facts more carefully than you seem to have done, and that, while studying them, you should remember that the sins of others are a poor excuse for our own". Russell also reminded Thomas that he had overlooked another highly pragmatic point: "If opposition to real evils in the West is undertaken only by Communists, this gives Communists an immense propaganda advantage, and makes American talk about a 'free world' appear nothing but hypocrisy". With this last assertion, Russell rested his case: He had done his best to get Thomas to develop a broader, more relativistic perspective about the Cold War.

Thomas' rebuttal, which appeared immediately after Russe11's in the 18 February 1957 issue of The New Leader 
further accentuated the disagreement between the two men. ${ }^{9}$ It revealed that an important part of their dispute centered on questions about the validity of the published sources which Russell cited in support of his view of the state of American liberties. Opening with the admission that Russe11's letter had "... one excellence which I welcome ... that he is not consciously or unconsciously anti-American über alles", Thomas hastened to add that: "Otherwise, his letter is scarcely relevant to anything I wrote". He then dismissed all of Russe11's charges because they would have been applicable only to an indiscriminate defender of McCarthyism which, of course, Thomas was not.

Thomas then reiterated his original complaint against Russell's introduction to the Lamont book, "... that his exaggeration grossly weakened the force of our constructive criticism of our country's failure to live up to its own highest ideals". To this original charge, Thomas added another: the "... fear that unwittingly he plays into the hands of the spiritual neutralists by going as far as he does in denouncing America as well as Russia". True to his earlier social gospel background, Thomas could not escape his penchant for viewing events--including the Cold War--in moral terms.

Thomas then denied that he had criticized Russell for writing a preface to a book by a fellow-traveller and insisted he had criticized him instead on two other grounds: first, for accepting without investigation obviously controversial statements in a fellow-traveller's book; and second, for exaggerating beyond the topics dealt with in the Lamont book about the status of civil liberties in the United States. In typical Thomas style, he presented his critique of Russe11 in a point by point rebuttal of the four principal sources which the Englishman had cited in support of his position.

The first part of Thomas' rebuttal dealt with Russell's use of Lowenthal's The Federal Bureau of Investigation as the basis of his condemnation of the F.B.I. Thomas dismissed the book as "unconvincing" and Russell's assertion that supporters of Black equality and the U.N. were liable to coercion by the F.B.I. as "fantastic". He assured Russel1 that he had spoken in the South in support of desegregation many times and had never been molested by the F.B.I., which rather had done some good work against racial demagogues in the South. Thomas reminded Russell that Lowenthal's reputation was tainted by his ties with known Communists, including an assistant who had worked with the East German Communists and

"Norman Thomas Comments", The New Leader, 40 (18 Feb. 1957), 18-19. defected to the Russians. As an antidote, Thomas recommended that Russell read Don Whitehead's Story of the F.B.I. for a more balanced view of the Bureau's activities.

Turning to Russe11's reference to Belfrage's The Frightened Giant Thomas admitted that he had not read the book but added that he had seen a book review of it in the London Sunday Times by Dwight Macdonald, and that he was familiar with Belfrage's case. Thomas 'said he agreed with the reviewer that Belfrage should not have been deported from the United States; but, nevertheless, the Belfrage case and many others prove that aliens in America have a "... far better defense against summary deportation than in England where the Home Secretary's power appears to be absolute". Thomas added that there was swarn and uncontradicted testimony that Belfrage was an agent in a Soviet espionage group and that he had pleaded the Fifth Amendment rather than contradict this testimony.

Russell's first two points, according to Thomas, were of questionable validity because they were based on tainted sources written by pro-Communists. However, Russell's last two pieces of evidence did not rely on such "tainted" documentation. Thomas, therefore, was forced to develop different lines of argument to refute them.

Regarding Russe11's use of the Rosenberg case as an example of the miscarriage of American justice, Thomas conceded that Sharp's Was Justice Done?, which Russell had used to support his opinion of the case, was an "... honest book in which the author differs from the judgment of a jury". Yet, Thomas added, "Neither he nor the able lawyers of the American Civil Liberties Union found a denial of civil liberties" Thomas then stated that he had opposed the death sentence on humanitarian grounds, but that he questioned Sharp's ability to judge fact and the law better than a jury and a court. As he put it:

I would, however, expect Bertrand Russe11 to agree with me that an American jury is not to be regarded as neces sarily bigoted or a foe of freedom when it finds on evidence, not wholly convincing to Professor Sharp, that a Communist or Communist sympathizer is guilty of a crime which at the time was counted in Communist theory not as a crime but as a golden deed performed in loyalty to that country which, according to the Communist Manual, was the "only fatherland of the workers".

Here, he combined the traditional American faith in the judicial process with a belief developed out of bitter experience that Communism was by its very nature a disloyal, subversive force. 
The last piece of Russell's evidence which Thomas confronted was the letter from the persecuted professor which appeared in the London Observer. Thomas admitted the existence of such cases and cited his own frequent denunciations of them. However, he also insisted that there was another side to the story.

But I would remind Lord Russell that there are in America 2,000 colleges with more than 200,000 professors, the overwhelming majority of whom remain undisturbed on their jobs even though many of them are self-proclaimed supporters of a very absolute type of freedom for Communist professors, regardless of what Communism teaches or practices in the field of academic freedom.

To Thomas, Russell's evidence on this point was too limited to prove his point from a quantitative standpoint. He charged Russell with relying on the exception rather than the rule.

Thomas concluded his rebuttal by emphasizing that Americans needed the help of men of Russell's stature if they were to emerge victorious in their struggle for civil rights. After appealing to him to "... refrain from the exaggeration which gives our opponents so much opportunity to scoff", Thomas urged Russel1 to read about the more positive aspects of the American scene--such as Martin Luther King's use of Gandhian nonviolent tactics--so that he might develop a more balanced perspective. This was important, Thomas insisted, because "Fortunately, the facts, bad as some of them are, tell a different story from the one Bertrand Russell has believed."10 The chasm between Russell and Thomas' views on the state of American civil liberties was vast and deep. Neither could accept the major premise of the other's position.

Despite the foregoing, the shift from conflict to cooperation between Bertrand Russell and Norman Thomas was not long in coming. It was made possible because, as Russe11 had reminded Thomas in the concluding paragraph of his open letter, "You and I, throughout our long lives, have been devoted to not dissimilar causes, and it is much to be regretted if differences about this or that make our divergence seem greater than it is". One of these "not dis-

${ }^{10}$ Ibid., p. 19; see also the much more friendly personal letter which Thomas sent to Russell thanking him for his open letter. In it, Thomas politely reiterated his position but expressed relief that the two were not as far apart as he had originally thought. Thomas to Russe11, 6 March 1957, Russell Archives. similar" causes was a passionate concern which both men shared for the creation of a peaceful world, free from the threat of nuclear holocaust. Though there is no specific mention of it in Russell's autobiography, the collection of Russe11-Thomas correspondence in the Bertrand Russell Archives amply illustrates the working relationship which the two men achieved in their search. for peace in the closing years of their lives.

The essential part of that relationship involved their joint efforts to publicize the dangers which they saw in the development and proliferation of nuclear weapons. Writing to Russell in August 1958, Thomas discussed the results of their unsuccessful attempts to act as plaintiffs in lawsuits instigated in the United States, Britain, and the Soviet Union against the deployment of nuclear weapons in these countries. ${ }^{11}$ After informing Russel1 that the attempt to initiate a suit in federal district court had failed and that he would try to initiate an appeal, Thomas revealed the strategy which they were pursuing when he said: "I rather expected the unsuccessful conclusion, but I was disappointed that the press and other agencies of communication played the whole business down". Thomas then told Russe11 how the media had likewise played down the precedent which he and others had established by appearing before the U.N. Trusteeship Council "... independent1y, but in support of the Marshallese people against the use of their islands for nuclear tests".

The final portion of the letter indicates that Russell and Thomas were actively exploring a wide variety of direct action proposals that would lessen the chances for war. In it, Thomas suggests that they consider the suggestion of his friend, Irving Caesar, who had proposed that the United States and the Soviet Union exchange hostages as an insurance against attack and a sign of their peaceful intentions, and that a conference of businessmen be held "... to explode the notion that the arms race is a necessary and safe means of bucking up the economy".

In December 1959, Thomas wrote Russell to thank him for the latter's birthday greetings. In that letter, Thomas revealed how much he had been influenced by Russell's efforts on behalf of peace.

I was listening just the other day to a record of one of your speeches and was again reminded of the extraordinary debt we owe you in these days for the service you are rendering to a rational peace in a pretty irrational world. You and what you are saying are a great asset to us in

\footnotetext{
${ }^{11}$ Thomas to Russe11, 8 Aug. 1958.
} 
America as everywhere else where men will listen to the voice of reason.12

Thomas, in the closing years of his long life as an activist, had found someone who shared his most cherished reform goal and the belief that it must be pursued with passion.

The respect which Thomas felt for Russel1 explains the persistence of his attempts to secure Russell's active support of American anti-war activities. Writing in February 1960, Thomas informed Russe11 that the Committee for a Sane Nuclear Policy (SANE) had scheduled a mass meeting for Madison Square Garden on 19 May to express support for the Geneva negotiations over the proposed ban on nuclear testing. ${ }^{3}$ Thomas explained that the rally committee hoped to print a long program, part of which could be circulated later in a pamphlet that would illustrate "... that understanding of the necessity of disarmament is widespread throughout the world". He then asked Russell to contribute a brief statement for the program. Subsequent correspondence indicates that he was well pleased with the statement that Russe11 wrote and the outcome of the rally. ${ }^{14}$

There is no doubt that the activities of the American SANE Committee, and particularly its use of the mass rally technique, had a profound effect on Russell and the British peace movement. Encouraged by these efforts and the ideas of Ralph Schoenman, a young American political activist living in England, Russell broke with the older, less activist Committee of Nuclear Disarmament and along with Rev. Michael Scott formed a new group, the Committee of 100 . This group organized a mass movement which used the tactic of nonviolent resistance in hopes of preventing the development of nuclear weapons and agitated for unilateral British nucleax disarmament. The mass meetings organized by the group beginning in February 1961, attracted large crowds and immense publicity. ${ }^{15}$

Thomas also made use of his position as chairman of the Post War World Council, an organization devoted to the creation of a world federation of nations, to reinforce his efforts for peace and disarmament. It was in his capacity as chairman and editor of the Newsletter of that organization that he prevailed upon Russell in December 1960 to write an article which would present his "... own particular

${ }^{12}$ Thomas to Russe11, 8 Dec. 1959.

${ }^{13}$ Thomas to Russell, 5 Feb. 1960.

${ }^{14}$ Thomas to Russe11, 18 March 1960 and 24 May 1960. A

copy of the printed statement is in the Russell Archives.

${ }^{15}$ The Autobiography of Bertrand Russell; The Final Years: 1944-1969 (New York: Bantam Books, 1969), pp. 144-9. view of the disarmament subject, mentioning what you are urging in England but also advising the U.S."116

Russell responded with an article, "Approaches to Dis armament", which was pub1ished in the January 1961 P.W.W.C. Newsletter. 17 In it, he expounded the virtues of neutralism as a path to peace. He emphasized that: "For all sane men the leading problem in the present international world must be the prevention of an all-out nuclear world war". Emphasizing the importance of distinguishing what should be done by the United States and Russia, the two nuclear giants, from the responsibilities of their allies and nuclear giants, Russell argued that the two super-powers should abolish ali weapons of mass destruction and establish a thorough inspection system that would be policed by neutrals. Since this best solution was not possible because of greater American than Russian intransigence, he continued, it was thus important to ascertain what should be the policies of such allies of the United. States as Britain. Russell rejected out of hand the two major arguments advanced by those who favoured Britain's participation in NATO: That it made Britain less exposed to danger from Russia and that it enabled the British abled the British to have greater influence on the American government. He countered these arguments by insisting that Britain would stand less danger of a Soviet attack as a neutral and that it could work far more effectively for reconciliation of the East and West if it operated from outside the two blocs.

With regard to American pacifists, Russell defined their main task as the need "... to combat the fanaticism which would suggest that we have to choose between the end of Man and the victory of Communism". Such a "better dead than red" view was false, he maintained, first, because it false$1 y$ assumed that the easing of tensions would make a Communist victory inevitable; and second, because a Communist world would still leave more room for the future of man than one with no one left alive. Russell also asserted that the ideological conflict between the East and West was insincere because: "The West is suppoed to be fighting for freedom, but the most ardent advocates of the fight for freedom are also the most ardent advocates of the suppression of such freedoms as the West still enjoys". Russell came close at this point to a position he had developed earlier in his confrontation with Thomas about the danger of suppressing civil liberties in pursuit of security.

\footnotetext{
${ }^{16}$ Thomas to Russe11, 14 Dec. 1960.

1 "Approaches to Disarmament", Post War World Counciz Newszetter (Jan. 1961), 2-4.
} 
Thomas, in sharp contrast to his earlier objections to Russe11's more specific depiction of civil liberties in America, expressed strong approval of Russell's article. In In a letter written in January 1961" he asserted: more people who read it the better" and urged Russell to circulate it freely. ${ }^{18}$ He compared the results of their demonstrations against the opening of Polaris missile-armed demonstrations andes and Britain. nuclear submarine bases in the United States and Britain. Thomas thanked Russel1 for some anti-nuclear leaflets he had sent and stated that he did not understand the British government's logic in accepting the Polaris base. Comparing the results of the American and British activition he noted: "In pragmatic terms our situation is not think that the brave protestors same as yours and I do not think that the brave protestors at New London have been very effective". Thomas, however assured Russell that he remained optimistic about what he felt would be other "effective initiatives" in disarmament.

Subsequent correspondence from Thomas to Russell included evidence of their continued cooperation in their efforts on behalf of peace and other humanitarian causes. In Novemon behalf of peace and at the behest of the editors of Dissent ber 1961, Thous a magazine, invited Russell to come to the United stasell's speak on "the road to peace he alth, two things which he also shared, Thomas wrote: "You could do us in America much good by appearing but by no means do I want to urge you unduly" $y^{\prime \prime}$ Russell did not appear.

In October 1963. Thomas wrote Russell including a copy of a column he had written for the Denver Post which defended the civil rights of Soviet Jews and urged that world ed the civil rights of Soviet Jews and urgedf. ${ }^{\circ}$ Thomas public opionion be mobilized on their behalf. Thomas then proposed to Russe11: "If you think it is sufficiently in accord with the admirable letter that you plan to send Khrushchev and if you think my signature will help rather than hurt in view of the statement to which I refer in the column you may use my name". We have no record of Russe1 response to Thomas, but the current discussions of the status of Soviet Jews and the broader but related question of dissident rights in the Soviet Union had their origins in the early efforts of Russe11, Thomas and others of like mind to publicize the problems of those who dared to be

${ }^{18}$ Thomas to Russe11, 9 Jan. 1961. Russe11 had the article reprinted in Peace News, no. 1287 (24 Feb. 1961), 9.

${ }^{19}$ Thomas to Russe11, 13 Nov. 1961.

${ }^{20}$ Thomas to Russe11, 14 0ct. 1963; see the copy of the rticle marked "For Release 0ct. 10" in the same folder as Thomas' letter in the Russell Archives. different and to generate public opinion on their behalf. Their involvement in defense of Soviet Jews indicates that their efforts on behalf of peace were but one aspect, though a very important one, of the humanist philosophy which Russe11 and Thomas shared.

One cannot help but be struck by the differing perceptions of the state of American civil liberties which Russell and Thomas held in the late 'fifties. Russell's political experience, it should be remembered, was with the Labour Party which so dominated the left side of the British political spectrum that it was never seriously threatened by Communism. Thomas' experience, on the other hand, was as a leader of the American Socialist Party, which had never established itself as a dominant force in American politics. He had bitter memories of the divisive and disruptive tactics which the C.P.U.S.A. had employed against his party in the 'thirties and the World War II years.

These experiences had left Thomas convinced that Communist loyalty to the Soviet Union had created a unique phenomenon, one which posed a serious threat to American security because Communists did not play by the rules of the game required by a democratic political system. ${ }^{22}$ Thus, while Thomas sincerely deplored the excesses of McCarthyism, he also favoured the use of legal means to suppress the subversive activities of Communists. Lord Russell's preoccupation with the atmosphere of fear created by the American thirst for internal security quite naturally left him most impressed with the sources which emphasized the worst aspects of the situation. Unfortunately, several of the sources which he relied upon were either Communists themselves or, like Lamont, fellow-travellers who, according to Thomas, were distorting the situation in America for their own purposes.

Thus, the Russe11-Thomas clash underlines the critical role which experience plays in shaping an individual's position on controversial issues. It also reminds us that much of the contemporary political writing of the Cold War years was in the form of propaganda or adversary literature, a fact which suggests the need for modern historians to approach that writing with a great deal of caution. Perhaps its best use is that which Russell and Thomas inadvertently demonstrated in their exchange, that is, that it reveals much more about the argumentation of the Cold War than it

${ }^{21}$ James C. Duram, Norman Thomas (Boston: Twayne, 1974), pp. 29 and 102-7.

${ }^{22}$ Norman Thomas, "Civil Rights Not Conspiracy", New York Times Magazine, 7 Jan. 1951, pp. 11, 41-2, 44. 
does about its causation.

The movement from conflict to cooperation illustrated in the Russe11-Thomas correspondence suggests that the American preoccupation with internal security proved to be a divisive issue for only a short period of time between the two leaders. The passion for peace which both shared proved to be far stronger than their differing perceptions of the American scene. Writing in his autobiography, Russell characterized the sense of urgency which dominated his thinking about peace in the late 'fifties:

I felt that I must again do something to urge at least a modicum of common sense to break into the policies of the two Great Powers, Russia and America. They seemed to be blindly, but with determination, careering down a not very primrose-strewn path to destruction, a destruction that might--probably would--engulf us al1. ${ }^{23}$

Norman Thomas was likewise motivated by the same sense of urgency. Writing in April 1959, he stated:

Perhaps the greatest change in our lifetime--and this may hold true for all of human history--has to do with the implications of nuclear energy. Atomic weapons, paradoxically, have shattered the institution of the military as a factor in national policy. If we want to serve the cause of freedom, protect the world against aggression, and lay the basis for a better world, it becomes necessary to devise means other than force or the threat of force. ${ }^{2}$

Driven by their fears of a nuclear holocaust, both Russell and Thomas sought a means to break out of the Cold War frame of reference which both believed perpetuated the insecurity which made eventual confrontation inevitable. Because they shared this perspective, Russell's work with the Committee of 100 and Thomas' work with SANE created an unshakeable basis for cooperation, one which transcended their sharp disagreement about the impact of the Cold War on American civil liberties.

Department of History

James C. Duram Wichita State University

The author wishes to express his thanks to the National Endowment for the Humanities for the financial assistance which made this study possible.

${ }^{23}$ Autobiography; The Final Years: 1944-1969, p. 134.

24 "Are We As Right As We Think?", Saturday Review, 42 (18 Apri1 1959), 13; see also Thomas, The Prerequisites for Peace (New York: Norton, 1959), passim. 